INTERNATIONAL JOURNAL OF MULTIDisciplinARY RESEARCH AND ANALYSis

ISSN(print): 2643-9840, ISSN(online): 2643-9875

Volume 04 Issue 06 June 2021

DOI: 10.47191/ijmra/v4-i6-22, Impact Factor: 6.072

Page No.- 829-836

\title{
Arrangements of Authorities Pd. Medan City Market in the Making of Cooperation Contracts and Management of the Medan Separate Market
}

\author{
Novi July Rosani Zulkarnain ${ }^{1}$, Ria Sintha Devi ${ }^{2}$ \\ 1,2Universitas Darma Agung
}

ABSTRACT: Agreement/contract for place of business in the context of restoration/rejuvenation of the Medan Municipal Petisah Market project which was made and signed by the Medan Municipal Government with PT. Gunung Karya Kencana Sentosa (PT.GKKS) on July 24, 1993 with agreement/contract number 511.2/13155 is a form of build operate transfer (BOT). The problem in this research is related to the contract arrangement for the place of business in the context of the development and management of the Petisah Market, how is the authority of PD.Pasar Kota Medan in making cooperation contracts and problems and their solutions in the development and management cooperation of the Petisah Market. This research method uses a qualitative method that is juridical normative. Based on the formulation of the problem, this research also conducts interviews and direct observations of the results of development carried out by PT. GKKS as well as the management of Medan Petisah Market which is divided into management areas based on the contract, namely the first floor for PT. GKKS and the second floor for the third floor for PD. Pasar Kota Medan. Making every contract in the PD environment. Medan City Market before and after regional autonomy is the same. PD. Medan City Market is authorized and has the right to make a cooperation contract with any party as long as it must be approved by the Medan City PD.Pasar Supervisory Board. Therefore, the Petisah Market contract is null and void because the Medan City Government represented by the Medan Mayor is not authorized to be a party to the cooperation contract because the Petisah Market which is the object of the contract/agreement is not owned by the Medan City Government since the change in the Medan City Market Service institution. become a PD. Medan City Market.

KEYWORDS: Agreement, Development, Management

\section{INTRODUCTION}

Agreement/contract for business premises in the context of restoration/rejuvenation of the Medan Municipal Petisah Market project which was made and signed by the Medan Municipal Government with PT.Gunung Karya Kencana Sentosa (PT.GKKS) on July 24, 1993 with agreement/contract number 511.2/ 13155 is a form of cooperation to build for delivery or build Operate Transfer (BOT). This collaboration was carried out due to the lack of financial capacity of the Medan City Government to carry out the restoration/rejuvenation of the Medan Petisah Market. Moreover, at that time it was approximately one month later that the legal status of the agency that managed markets in Medan City, namely the Medan City Market Service became a Regional Company. (PD) Pasar Medan City, all assets of the Market Service are handed over to PD. Market with the minutes of June 7, 1993.

This is intended to increase regional income which is referred to in the law as regional original income (PAD) so that its management is more professional, to manage or manage all traditional markets including Petisah Markets to be more efficient and effective.

Previously, Medan Petisah Market was built by the Medan City Government in 1960 and 1977 on a land area of 20,000 M2 while the building area is 10,789 M2. Since the declaration of the year of Medan City tourism in 1991, the Medan City Government has begun to organize traditional markets located in the city's core, namely Petisah Market, Market Center, Hong Kong Market and Peringgan Market to reduce the cluttered face of the city due to the existence of traditional markets. All of these traditional markets were built in the form of BOT cooperation with the private sector.

Law Number 5 of 1962 which is the legal umbrella for the establishment of Regional Companies throughout Indonesia and has a close relationship with the law on Regional Government or Regional Autonomy which is constantly changing in 


\section{Arrangements of Authorities Pd. Medan City Market in the Making of Cooperation Contracts and Management of the Medan Separate Market}

accordance with the development of the pattern of government since the independence of the Republic of Indonesia. Namely, starting from Law No. 1 of 1945 adopting a formal household regional autonomy system, Law No. 22 of 1948 grants the region the widest possible autonomy and medebewind rights. Law Number 1 of 1957 adheres to the widest possible real autonomy system, Law Number 5 of 1974 adopts a real and responsible regional autonomy system. Law Number 22 of 1999 adheres to the principle of broad and real regional autonomy and changes Lastly, Law Number 32 of 2004 adheres to broad, real and responsible regional autonomy.[1]

The Petisah Market Contract signed by the Mayor of Medan and the Director of PT. The GKKS has divided into two stages of development. In both stages, compensation is given to PT. GKKS is in the form of division of management area, namely the first floor for PT. GKKS and the second floor are for Medan City Government but managed by PD. Medan City Market.

The contract has been amended five times and the last was addendum V, which was signed on March 13, 2003, entirely due to technical difficulties in the construction work. Nevertheless, the parties in the entire Addendum have not changed, namely the Mayor of Medan who represents the Medan City Government and the Director of PT.GKKS.

In the first phase of construction, there were not many problems regarding the management of the Petisah Market. But when the construction of phase II began, many problems arose such as delays in the implementation of development, lack of maintenance from PT. GKKS on the location of the shelter both the physical condition of the barracks and the electricity. So that there was a fire in 2003 and the height of the first floor in stage II which was not the same as the height of the first floor in stage I and after the construction of stage II was completed the provision of facilities to traders on the first floor was not satisfactory.

All of these problems can cause a reduction in the income of Medan City Market PD, such as the growth of informal/street vendors, cleanliness, market facilities, security and others related to market operations. So that the traders do not want to pay the contribution which is their obligation to PD.Pasar Kota Medan. While the traders on the first floor do not want to pay maintenance fees to PT.GKKS. This makes it difficult for PT.GKKS to pay royalties to PD. Medan City Market. Of course, the implications of the disobedience of traders in carrying out these obligations can reduce the distribution of operating profits to the Medan City Government treasury provided by PD. Medan City Market at the end of each year as a dividend.

Under these conditions, PD.Pasar Kota Medan reports to the PD Supervisory Board. Medan City Market which is chaired by the Regional Secretary (Sekda) of Medan City is then forwarded to the Mayor of Medan as the parties to the contract to resolve all problems that arise relating to PT. GKKS. However, this bureaucratic mechanism also does not guarantee a fast and accurate problem solving, because the response to reports given by the Medan City Government always takes a relatively long time. This is due to the many problems that occur in the city of Medan which must also get the attention of the Medan City Government. This should not have happened if the Petisah contract that signed it was the PD. Medan City Market.

\section{THEORY FRAMEWORK AND CONCEPT FRAMEWORK}

A. Theoretical Framework

The word agreement can be constrained very popular among the people. If only seen from a translation perspective, it is more in line with the Dutch word overeenkomst used by the Civil Code. As for the word "contract" is usually intended for an agreement that is held in writing or held among businesses (the world of business).[2]

According to Sir Henry Maine in legal theory inspired by the principles of historical evolution that contracts are derived from status, namely legal conditions that have certain characteristics such as caste, slaves and trade unions which were pioneered by industrial and capitalist societies so that in the end created freedom of contract. This freedom is also not influenced by dures, mistakes and fraud.[3]

Previously, Contract Law was considered a Civil Law Institution after the 20th century. Due to the emergence of functional legal teachings that gave birth to standard contracts with the principle of freedom of contract, they are controlled by State Administrative Law (HAN) regulations which contain elements of public interest. So Contract Law in the business field is part of Economic Law (Droit de l'economie) rather than Civil Law.[4]

If examined from the form of cooperation stipulated in the Decree of the Minister of Home Affairs of the Republic of Indonesia (Kepmdagri) concerning Procedures for Cooperation of Regional Companies with Third Parties, namely joint ventures and joint operations, then the Petisah Market contract is in the form of cooperation. management (joint operations). This cooperation in Presidential Decree (Keppres) Number 80 of 2003 and Government Regulation (PP) Number 6 of 2006 concerning Management of State/Regional Property is called a Build/Rehabilitation Contract which is divided into several forms and based on this Presidential Decree the form of contract cooperation The Petisah Market is in the form of Build Operate Transfer (BOT). But at that time there were no regulations governing this. 


\section{Arrangements of Authorities Pd. Medan City Market in the Making of Cooperation Contracts and Management of the Medan Separate Market}

The definition of BOT based on these two regulations is that "Build to handover" is the use of state/regional property in the form of land by other parties by constructing buildings and/or facilities and their facilities. Then it is utilized by the other party within a certain period of time that has been agreed upon, and then the land and buildings and/or facilities along with their facilities are handed over after the end of the period.

According to the Decree of the Minister of Finance of the Republic of Indonesia Number 248/KMK 04/1995, it is stated that what is meant by Bangun Guna Handover (BOT) is a cooperation agreement entered into between the holders of land rights giving the investor the right to construct buildings during the period of the agreement and transfer ownership. building to the Land Rights Holder after the agreement period ends.

This BOT agreement is a new agreement that is not specifically regulated in laws and regulations that are always used by domestic and foreign investors who take economic benefits from development investments that have been made for a certain period of time. So that it can return the costs that have been incurred starting from the implementation of feasibility studies, procurement of goods and equipment until the construction period.

In other words, this BOT is where the First Party as the Exclusive Right Owner or Land Owner without relinquishing its rights to the land. Binds itself to hand over control over the land to the Second Party who commits himself to make development investments at his own expense and manage it with or without certain benefits agreed upon to the First Party during the contract period and after the contract period ends. Then the Second Party returns to the First Party the control over the land and buildings in good condition to operate.

\section{Conceptual Framework}

An agreement or also called a contract is an agreement that has been mutually agreed by two or more people in good faith to perform an act justified by the applicable laws and regulations.

A cooperation agreement is an agreement that has been mutually agreed upon by two or more people to carry out an act together which is justified by laws and regulations with different capital owned by both parties but generates profits for both.

Petisah Market Development is an activity to remodel, renovate, rehabilitate, modernize Petisah Market for commercial and social purposes.

Medan City Government is a City Regional Government led by a regional head called the Mayor. Based on the Government Regulation of the Republic of Indonesia Number 84 of 2000 concerning Guidelines for the Organization of Regional Apparatus, City Government is the Regional Head and Autonomous Regional Apparatus.

Limited Liability Company (PT) Gunung Karya Kencana Sentosa is a national private company engaged in property as an investor in collaboration with the Medan City Government in building and managing the Medan Petisah Market.

Formal Traders are traders who occupy a place to sell in the market building. If you are on the second floor, you already have ties to PD.Pasar Kota Medan through the appointment as stated in the lease right permit and if you are on the first floor, you have ties to PT. GKKS through a notarial deed.

Informal traders are traders who sell in places that are not intended as markets or places to sell, such as on roads, sidewalks, or other places. But for these traders, there are those who do not get legality and there are those who get legality from PD.Pasar Kota Medan.

\section{RESEARCH METHODS}

\section{a. Research Specification}

This study uses a qualitative method that is juridical normative. Based on the formulation of the problem, this study then conducted observations through direct observation of market management.

\section{b. Research sites}

The research location is the PD Office. Medan City Market which is located on Jalan Razak Baru, 3rd floor No. IA Petisah Market

Medan. This office building is also integrated with the selling places on the first and II floors.

c. Data Collection Techniques

The technique in collecting data in this study is to use documentation techniques, by collecting library materials, company documents and legislation.

d. Data Collection Tool

The data collection tools used in this research are document studies to obtain secondary data and interviews with informants to obtain primary data.

e. Data analysis 


\section{Arrangements of Authorities Pd. Medan City Market in the Making of Cooperation Contracts and Management of the Medan Separate Market}

To analyze the data, a qualitative approach was used, namely by analyzing it in depth and the results of the study were discussed by describing it.

The first step in this research is to start by collecting secondary data which includes primary legal materials, secondary legal materials and tertiary law.

The last step is to perform data analysis, namely the implementation of PD status. Medan City Market on management cooperation.

\section{DISCUSSION}

\section{A. Legal Studies in Contracts for Business Places in the Context of Development and Management of Medan Petisah Market}

To find out whether the contract for the place of business in the context of the development and management of the Petisah Market is a contract recognized by law, the contract must have two things, namely being made legally and agreeing on the determination of rights and obligations as well as legal consequences. Therefore, at a glance, it is necessary to know the meaning of law and contract law or commonly known as engagement law.

Theo Huijbers explained that there are no jurists who agree on a single definition of law even though the law is no longer something mystical but can be rationalized that can be reached by everyone in the conscious mind. As Huijbers quoted from Immanuel Kant "Noch Shucen Die Juristen Eine Definition Zu Ihrem Begriffe Vom Recht" (Juris are still looking for a definition for their understanding of law).[5]

The role or function of law is law as a means of protecting rights and interests (legal protection, rechtsbescherming). Then as a matter of fact, the law can be understood in its position as the output of political considerations, namely laws and regulations of the legal order (legal order, recht orde) which creates an orderly atmosphere so as to create legal certainty.[6]

In the Law of Engagement, there are a number of interrelated principles, namely the principle of freedom of contract, consensualism (conformity of will), belief, custom, binding force, legal equality, balance, morals, propriety, protection for the weak, the principle of legal certainty and an open system. 7]

In the compendium, contract law is equated with the law of engagement which is included in property law. Contract law is an open system. Although in this compendium it is also explained that the Civil Code (KUH Perdata) is New in Dutch Law, the Property Law is separated from the Law of Engagement. Property Law is included in book III and the Law of Engagement in book VI.[8]

Article 1320 of the Civil Code which is the most essential principle that determines the existence (raison d'etre, het bestaanwaarde) of the agreement. This principle also contains the meaning of "willingness" (wil) of the parties to achieve each other, there is a will to achieve each other, there is a willingness to bind themselves together. This will generates trust (vertrouwen) that the agreement is fulfilled. This principle of trust is an ethical value that originates from on morals because honorable humans will keep their promises. This principle has a close relationship with the principle of freedom of contract and the principle of binding force contained in Article 1338 of the Civil Code which reads "all agreements made legally apply as law for those who make". [9]

The word agreement can be considered very popular among the people. Some writers use the word "approval", because if it is only seen from a translation perspective, it is more in line with the Dutch word overeenkoms used by the Civil Code. The word "contract" is usually referred to an agreement that is held in writing or held in the business world (business world). [10]

\section{B. Mechanism of Contract Making for Business Places in the Context of Development and Management of Medan Petisah} Market

In making a contract in the government environment, it is usually not born or made easily and in a short time, but must go through a bureaucratic process in vertical and horizontal levels in accordance with the organizational structure and management of the task functions of each agency/institution that has been stipulated by regulations. legislation.

This condition is intended as a control as well as supervision over the implementation of regional/state asset and financial management which is inherent in the livelihood of the community. In other words, as an effort to prevent acts of abuse of authority in office for personal, group or group interests, for example this Petisah Market contract.

The Petisah Market Contract is realized as a joint development and management of a market complex building, which begins with one thought that becomes chronological in the manufacturing mechanism, namely:

1) A plan to restructure the Petisah Market environment that is more focused and reaches into the future with a more representative market building. 


\section{Arrangements of Authorities Pd. Medan City Market in the Making of Cooperation Contracts and Management of}

the Medan Separate Market

2) The rebuilding of the Petisah market is also intended as an effort for the City of Medan to become a Metropolitan City, which of course must be equipped with various facilities and infrastructure that are adequate and complex.

3) The limited financial capacity of the Medan City Government in building the Petisah Market in accordance with the progress of development and arrangement of the City of Medan.

4) There is support and approval as well as ratification from various institutions in this Petisah Market redevelopment plan, namely:

a. Regional People's Representative Council (DPRD) Medan City

b. Governor of North Sumatra

c. Minister of Home Affairs

5) A planning and review team is formed from the relevant agencies to discuss all aspects related to the Petisah Market development plan.

6) At the beginning of making the contract, it was guided by the Regulation of the Minister of Home Affairs (Permendagri) in force at that time which stipulates the participation of regional capital with commercial and mutually beneficial third parties, namely Permendagri Number 3 of 1986.

\section{Legal Basis for PD.Pasar Kota Medan to enter into a Cooperation Contract Kontrak}

The Medan City Government in the era of regional autonomy must be able to act as an entrepreneur. Therefore, as one of its manifestations is the ability of the Medan City Government to carry out the development of BUMD, so that city assets can be managed properly, efficiently, effectively, economically and profitably. One of the city's assets with great potential is the traditional market with a total of 54 markets which are generally created based on the embryo of a small community trade group, but some are specially built by the Government.

The strategic role of PD Pasar Kota Medan as a traditional market manager in the era of regional autonomy is as one of the economic actors and means of production in the region that can be used as a means of managing regional assets and developing workforce skills to realize people's prosperity. Apart from being a countervailing power to the existing economic strength through a partnership pattern, it is hoped that in the future many private companies will be interested in cooperating in the development of traditional markets.

In other words, the traditional management must be able to improve the quality of the market, namely the arrangement of a clean, neat, beautiful market environment with good and even modern supporting facilities. Also with the support of the Medan City Government through the provision of road accessibility, traffic flow and transportation systems that integrate the outer and inner rings of the city. So that the existence of traditional markets is still able to keep up with the development of Medan City which has the character of a Metropolitan City, namely competing with modern markets that have been increasingly built.

The above desire cannot be separated from the ability to manage finances effectively and efficiently. In fact, since its establishment in 1993, there has been no use of PD money. Medan City Market is good for rejuvenating/rebuilding activities and the procurement of new traditional markets, one of which is the Petisah Market. All traditional market development is carried out with a partnership pattern. This is a form of efficiency in spending money and the effectiveness of money income by creating royalties and profit sharing. Therefore, the authority to carry out this partnership pattern is based on the applicable regulations, namely:

1. Law of the Republic of Indonesia Number 5 of 1962 concerning Regional Companies Article 14 paragraph (1) which reads "Directors represent Regional Companies inside and outside the Court", Article 15 paragraphs (1) and (2) which reads: "The Board of Directors determines policies under the leadership of the Region, the Board of Directors manages and controls the assets of the Regional Company."

2. Decree of the Minister of Home Affairs of the Republic of Indonesia Number 50 of 1999 concerning the Management of BUMD Article 6 which stipulates the duties of the Board of Directors who provide the responsibility of the board of directors in implementing cooperation with other parties, including leading and controlling all activities of BUMD, managing and managing BUMD assets, representing BUMD both and out of court. Furthermore, Article 7 also stipulates the authority of the Board of Directors, one of which is to sign legal bonds with other parties. Whereas in Article 8 it is stipulated that the Board of Directors requires the approval of the Supervisory Board in conducting cooperation which has direct implications for finances and assets or commonly referred to as return of assets (ROA) and return of investment (ROI).

3. The Decree of the Minister of Home Affairs of the Republic of Indonesia Number 4 of 1990 concerning Guidelines for Cooperation of Regional Companies with Third Parties can be seen and then declared no longer valid by the Decree of 


\section{Arrangements of Authorities Pd. Medan City Market in the Making of Cooperation Contracts and Management of the Medan Separate Market}

the Minister of Home Affairs of the Republic of Indonesia Number 4 of 2000. The Minister of Home Affairs of the Republic of Indonesia Number 43 of 2000 concerning Guidelines for Cooperation of Regional Companies with Third Parties.

4. Decree of the Minister of Home Affairs of the Republic of Indonesia Number 153 of 2004 concerning the Management of Separated Regional Goods Articles 30 and 31 which reads: "Unutilized PD or BUMD goods can be exploited through cooperation with third parties, cooperation with third parties as referred to in Article 30 is carried out based on the laws and regulations."

5. Medan City Regional Regulation Number 15 of 1992 which was amended by Medan City Regional Regulation Number 8 of 2001 concerning the Establishment of Medan City Market Regional Companies, the substance of this Medan City Regional Regulation adapts the Minister of Home Affairs Decree Number 50 of 1999. In Article 14 letter d of this Medan City Regulation it is determined that the Board of Directors in managing the company has the authority to sign legal bonds with other parties. Then Article 15 letters a and $d$ states that the Board of Directors requires approval from the Supervisory Board in matters of entering into cooperation agreements with third parties, entering into business cooperation agreements and or loans which may result in reduced assets and burden the company's budget.

6. Decree of the Mayor of KDH Level II Medan Number 188.342/834/SK/1994 concerning the Implementation of Regional Regulation KDH Level II Medan Number 31 of 1993 concerning the Use of Selling Places Article 4 states that the President Director of Regional Market Companies with the approval of the Supervisory Board may carry out expansion, rejuvenation and Market abolition.

BUMD as a business company based on the Regulation of the Minister of Home Affairs Number 3 of 1998 concerning the Legal Form of Regional Owned Enterprises can be legally formed as a Regional Company or Limited Liability Company (PT), each legal form is subject to the applicable laws and regulations for the legal form that.

By cooperating with third parties in developing this market, it is hoped that limited financial capacity will no longer be the main obstacle to realizing the mission carried out by the Medan City Government. Among other things is the development of economic facilities aimed at increasing the competitiveness of the city of Medan as a center for national and regional trade and financial services. As well as encouraging the growth of the business climate by building traditional markets in addition to modern markets in a service scale that is structured evenly in each city center and sub-district.

\section{Legal Status of PD. Pasar Kota Medan in the Cooperation Contract for the Development and Management of Medan Petisah Market}

In the Split Market contract, the relationship between PD. The Medan City Market is stated in Article 9 paragraph (4) which regulates the obligations of the first floor traders managed by PT. GKKS to comply with all applicable regulations in the PD environment. Medan City Market includes payment of contributions.

Article 9 has been discussed in the previous chapter that this article is an unstated cause (cautio indiscreta) binding the parties to comply with it. In addition, this article is still an object of a contract in the form of reciprocal achievements. This means that as a reciprocal of the granting of Management Rights received by PT. GKKS from the Medan City Government, then the obligation of PT. GKKS makes contributions to Floor merchant | and deposit it into the PD cash. Medan City Market every month.

When viewed from the fourth requirement of Article 1320 of the Civil Code, which is a lawful cause, then this agreement is null and void because the Mayor of Medan City has made a cooperation bond on an object that does not belong to the Medan City Government. As previously explained, in this Petisah Market contract the parties who promise are the Director of PD. Medan City Market with PT. GKKS.

This has become one of the weaknesses of the split market contract as stated in the results of the examination from the North Sumatra Development and Finance Supervisory Agency (BPKP). And then submitted to the Mayor of Medan on January 18, 2000 Number SP-02.03.01-105/DIV/2000 as an independent auditor's report on the financial statements of PD. Medan City Market for the financial year ending December 31, 1998 which stated three aspects of weakness in the development cooperation and management of the Petisah Market, namely aspects of the process of appointing a developer. The contents of the contract and management after the construction has been completed and further recommended, among others, to revise the contents and terms of the contract with transferred the name of the Medan City Government to the name of PD. Medan City Market and impose sanctions on Developers for complying with the contents of the contract including royalty payments.

The recommendation shows that PD.Pasar Kota Medan has authorization for asset management that has been submitted by the Medan City Government. In this regard, the Regional Secretary of Medan City stated to one of the daily newspapers published by the City of Medan that the APBD and the State Budget (APBD) APBN) in 2009 for the program for revitalizing traditional markets belonging to the Regional Government which was disbursed through the Department of Industry and Trade 


\section{Arrangements of Authorities Pd. Medan City Market in the Making of Cooperation Contracts and Management of the Medan Separate Market}

(Disperindag) failed to be used for traditional markets in Medan. Because the traditional markets that belong to the Medan City Government have been separated from regional assets and managed by the PD. Medan City Market. [12]

If in other areas the traditional markets are directly under the management of the Regional Government or Disperindag then the APBN funds can be used. And if the APBD funds are used for markets managed by regional companies, then it is in the form of capital participation by the Medan City Government but must go through the bureaucracy of DPRD approval at a plenary meeting and this process is also vulnerable to violation of regulations.

\section{CONCLUSIONS}

From the results of the discussion and data collection carried out on the contract/agreement between the Medan City Government and PT. GKKS in the construction and management of the Petisah Market in Medan City and the condition of the Petisah Market which is managed by PD. Medan City Market and PT. GKKS conclusions can be drawn as follows:

1. Contract arrangement for place of business in the context of developing and managing the Petisah Market when viewed from Article 1320 of the Civil Code does not meet the legal requirements of the third and fourth contracts, namely a certain matter and a lawful cause which is an objective requirement. This is because the object of the agreement, namely the land and physical property of the Petisah Market, are PD's assets. Medan City Market and is not a property of the Medan City Government.

2. Authority of PD. Medan City Market in making the cooperation contract has been fully provided by the legislation, namely the legal aspect that underlies the establishment of PD. Medan City Market, namely Law Number 5 of 1962 concerning Regional Enterprises, Law Number 32 of 2004 concerning Regional Government, Kepmdagri Number 50 of 1999 concerning BUMD Management, Kepmdagri Number 41 of 2000 concerning Procedures for Cooperation of Regional Companies with Third Parties and regulations other.

\section{BIBLIOGRAPHY}

1) Agussyah Putra, 2004, Effect of Modern Market Development on Traditional Markets in Medan Market Center (Case Study in Medan Market Center). USU Graduate Program Thesis, Medan.

2) Ahmadi Miru, 2007, Contract Drafting Law, Jakarta: Raja Grafindo Persada.

3) S. T. Kansil, 1986. Introduction to Indonesian Law and Legal Administration, Jakarta: PN Balai Pustaka.

4) Fernita Darwis, 2007.PDAM in the Era of Regional Autonomy, a New Paradigm of the Drinking Water Sector, Jakarta: A Pillar of Buffering Potential.

5) Hans Kelsen, Legal Theory. 2006, Translated by Jimly Asshiddiqie and Ali Safaat, Secretary General and Registrar of the Indonesian Constitutional Court, Jakarta.

6) H. Mashudi. dan Mohammad Ali Chidir, 1995. Chapters of Engagement Law (Elementary definitions).

7) Theo Huijbers, 1995. Philosophy of Law, Yogyakarta: Kanisius.

8) 2010, Contract Law, Contract Drafting Theories \& Techniques, Jakarta: Sinar Graphic.

9) J. Satrio, 1991. Cessie Subrogatie, Novatie, Compensation \& Debt Mixing, Bandung: Alumni.

10) Mars. SB. and Soulsby 1.206, Business law, translated by Abdul Kadir Muhammad, Covenant Law, Bandung: Alumni.

11) Mariam Darus Badrulzaman, 1993. KU H. Civil Code Book III of Engagement Law with Explanation, Bandung: Alumni.

12) —1994, Various Business Laws, Bandung: Alumni.

13) 1980. Standard Agreements, Developments in Indonesia, Scientific Works by Lecturers of the Civil Department at the Faculty of Law, USU Medan. (Unpublished).

14) Miza Nasution, Group IV Discussion Material, Legal Theory Course, unpublished.

15) R. Soetojo Prawirohamidjoyo and Safioedin Asis, 1982. Law of People and Families, Bandung: Alumni.

16) R. Soeroso, 1993. Comparative Law, Jakarta: Sinar Graphic.

17) R. Subekti, 1982. Principles of Law, Bandung: PT. Intermasa.

18) _ 1988. Aspects of National Engagement Law, Bandung: Image of Aditya Bakti.

19) Salim H.S, 2005. Developments of Law on Lanominate Contracts in Indonesia, Jakarta: Sinar Graphic.

20) Sudikno Mertokusumo, 1988. Knowing the Law (An Introduction), Yogyakarta: Liberty.

21) Syahril Effendy Pasaribu, 2004. PDAM, Operator of Clean Water and Drinking Water Services, Jakarta: Gratry Pratama.

22) Soedaryo Soimin, 1992. Human and Family Law Perspective of Western Civil Law/BW-Islamic Law \& Customary Law. Sinar Graphic, Jakarta. 
Arrangements of Authorities Pd. Medan City Market in the Making of Cooperation Contracts and Management of the Medan Separate Market

23) Sudarsono, 2002. Legal Dictionary, Jakarta: Rieneka Cipta.

24) Sunaryati Hartono, 1991. Legal Politics towards One National Legal System, Bandung: Alumni.

25) W. Friedmann, 1990. Legal Theory and Philosophy, Critical Study of Legal Theories (Composition 1), Jakarta: Rajawali.

26) 1990. Legal Theory and Philosophy, Philosophical Idealism \& Justice Problems (Order II), Jakarta: Rajawali.

27) Prodjodikoro, 1959. Principles of Covenant Law, Bandung:'S Wirjono Gravenhage: Vorkink-Van Hoeve.

28) _ـ 1964, Medant City Regional Regulation on Certain Agreements, Bandung: Sumur.

29) Indonesian-Dutch Legal Science Cooperation Foundation, 1978, Compendium for the Development of Modern Dutch Law, Gravenhage. Article

30) Aini Anyo Planologi,"Build Operate Transfer (Build Operate Transfer)". Via http://ainiplanologi.blogspot.com, accessed on October 5, 2010.

31) Anonymous, Down to Earth Nr 46, August 2000, Regional Autonomy, Society, and Natural Resources", via http://dtegn.apc.org, accessed on 5 July 2007.

32) The All-Indonesian Regency Cooperation Agency (BKKSI) "Prospects of Regional Autonomy in the Future", via http://www. apkasi.or.id, accessed on 5 July 2007.

33) Jusuf Eddy, "Regional Regulations and Investment Barriers", via http://www.minded-rakyat.com, accessed on January 1 , 2008

34) Kusumaningrum Febrina $V$, Contract, for questions regarding the contract process and procedure, through http://www.asiamaya.com, accessed on July 22, 2007

35) Laila, Sari, Desi and Diah. "Build, Operate And Transfer (BOT)", via http://kumpulancoretanila.blogspot.com, accessed on 5 October 2010

36) Imran Nating,"Understanding Contracts (National and International Dimensions)", via http://www.solutionlaw.com, accessed on 5 July 2007.

37) Machfud Sidik, "Optimization of Regional Taxes and Levies in the Context of Increasing Regional Finances", via http://dtegn.apc.org, accessed on 5 July 2007. 